\title{
ON PLEISTOCENE GLACIATIONS IN THE GERMAN ALPINE FORELAND
}

\author{
Gunnar Glückert
}

GlüCkert, GunNar 1974: On Pleistocene glaciations in the German Alpine foreland. - Bull. Geol. Soc. Finland 46, 117-131.

Investigations dealing with the moraine and gravel formations of the German Alpine foreland glaciers, the Salzach, Inn-Chiemsee, Isar, Lech, Iller and Rhine lobes, belonging to five major Pleistocene glaciations, the Donau, the Günz, the Mindel, the Riss and the Würm, have been compiled by the author and described in this paper. Glacial geological investigations were also carried out by the present author in 1971-1973 in the areas of the Salzach, InnChiemsee, Isar and Iller glaciers. These results, with some new observations, completing the text, are only summarized here, but partly have been presented in more detail in separate papers (Glückert 1973 a, b, 1974 and 1975).

Gunnar Gliickert, Institute of Quaternary Geology, University of Turku, SF-20500 Turku 50, Finland.

\section{Introduction}

The study of present and past glaciations was started in the Alps. Next to northern Europe and North America, the Alps are still one of the principal fields of glacial geological investigations.

During the Pleistocene epoch the Alps were several times covered with extensive glaciers belonging to former glaciations, called since Penck the Günz, the Mindel, the Riss and the Würm Glaciations. This basic division was worked out in considerable detail by Penck and Brückner (1901/1909) in the classical pioneer dockument »Die Alpen im Eiszeitalter I-III». The principal results, deeling with these four glacial stages of Penck and Brückner's, are still valid, but some additions have been made later.
In the vicinity of the city of Augsburg, in the foreland of the Iller-Lech Glacier, Eberl (1930) first demonstrated old gravel accumulations belonging to the fifth glaciation, the Donau, that existed before the Günz Glaciation (see also Graul 1949, Schaefer 1953 a, and Sinn 1971). According to Schaefer (1956), there exists a still older glaciation, the Biber Glaciation (e.g. Woldstedt 1967 p. 266, 1969).

\section{German foreland glaciers}

During the Pleistocene glaciations all the valleys of the Alps were filled with ice belonging to a huge Alpine ice cap. Only the highest mountain peaks rose as nunataks above the ice. Following long ice tongues flowed down the long Alpine valleys and diverged to form giant 


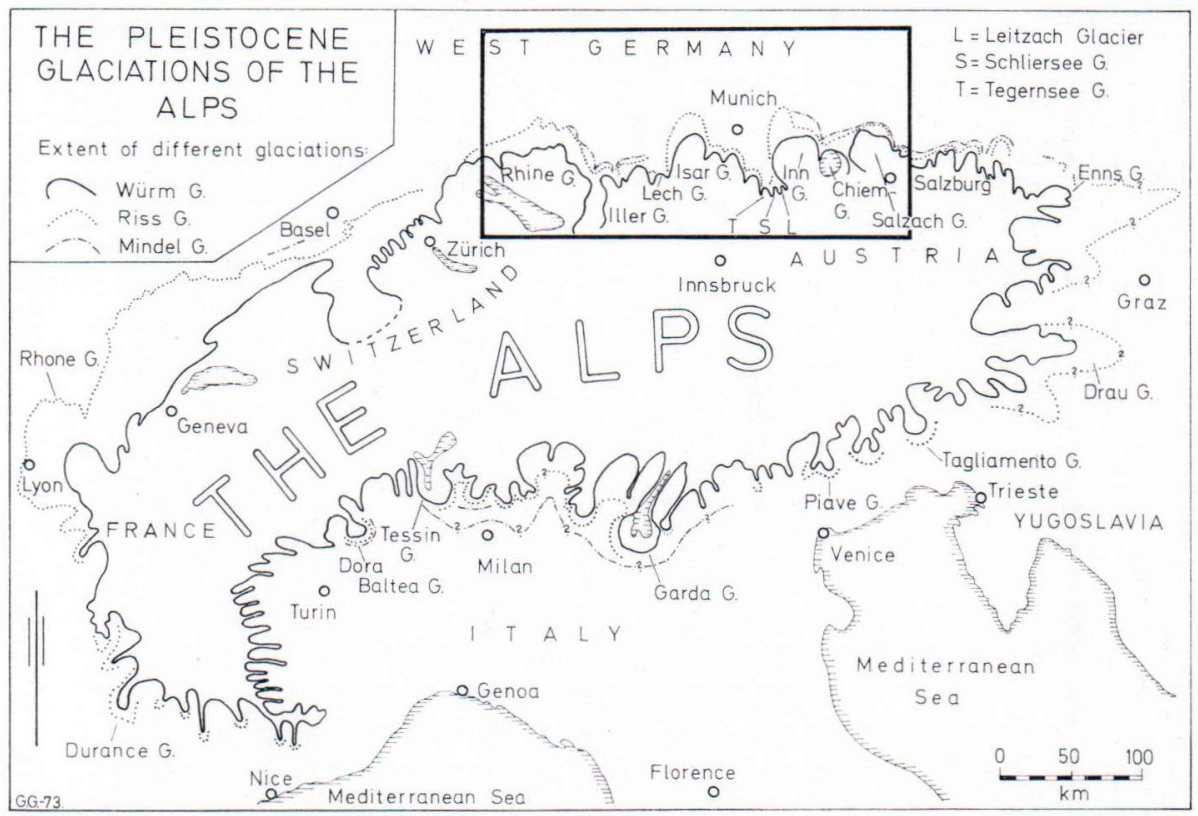

Fig. 1. The Pleistocene Glaciations of the Alps. Mainly after Penck and Brückner (1901/09) Antevs (1929) and Kaiser (1960). Area enlarged was studied closer (Fig. 2).

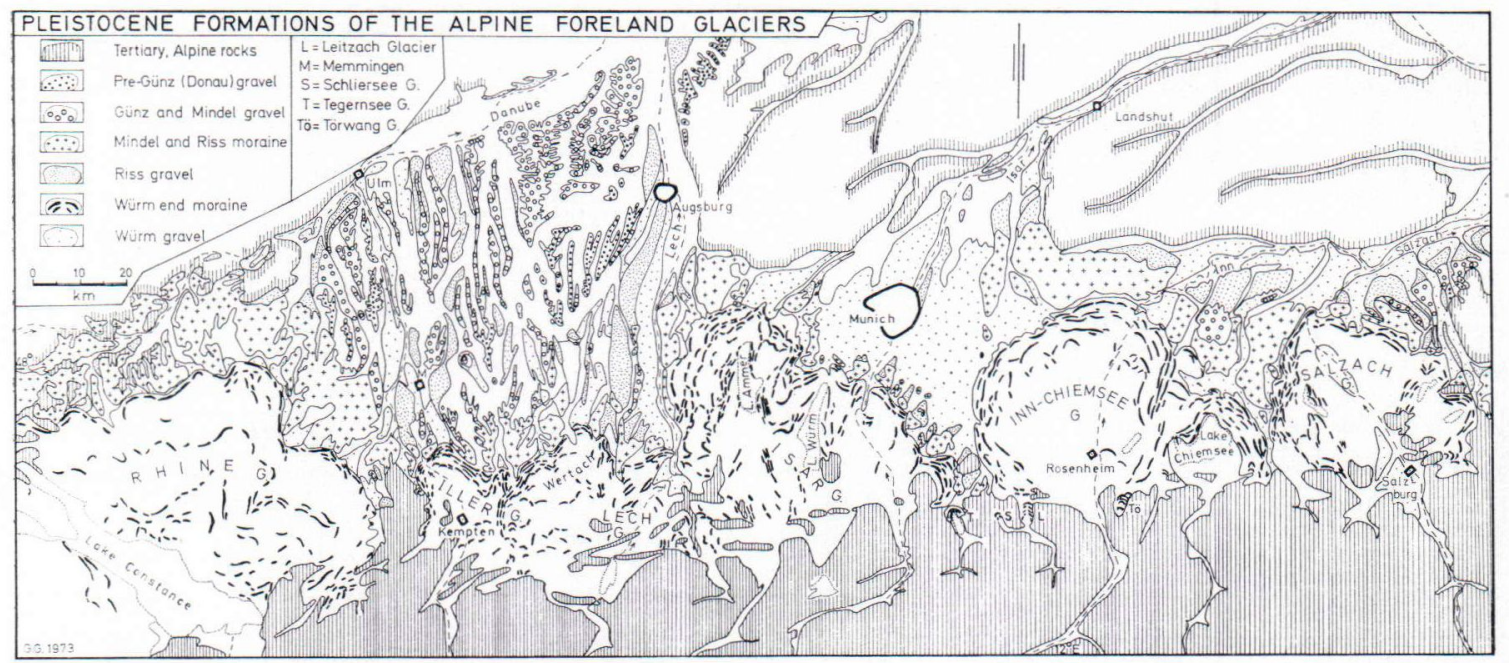

Fig. 2. Pleistocene formations of the Alpine foreland glaciers. Map compiled mainly from Eberl (1930), Graul (1949), Schaefer (1953 a), Sinn (1971, 1972), Glückert (1974), and the Geol. Map of Bavaria 1: $500000,1964$.

glacier fans in the northern foreland of the German Alps: the Salzach, the Inn-Chiemsee, the Isar, the Lech, the Iller and the Rhine piedmont lobes. In the foreland of the Alps the extent of these glaciers during different glaciations has been shown on the maps in Figs. 1 and 2.
The Pleistocene glaciers left large deposits of moraines and the meltwaters extensive gravel accumulations (outwash) in the foreland. The Pleistocene gravels consist mostly of hardened conglomerates of Alpine rocks, sedimentated on thick Tertiary basement of the old large Molasse 
basin, situating in the northern Alpine foreland. The basis of the stratigraphic classification of Pleistocene deposits by Penck and Brückner (1901/09) was to distinguish the different gravel terraces from each other and connect them with corresponding moraine formations. (see also Graul 1968 and Kraus 1968).

As a result of receiving a scholarship from the German Alexander von Humboldt Foundation, the author was able to study the former glaciated Alpine foreland of West Germany in 19711973. He also had the opportunity to take part in several geological excursions in the areas of the Salzach, Inn-Chiemsee, Isar and Iller Glaciers, arranged by Frau Dr. Edith Ebers, Prof. P. Schmidt-Thomé, Dr. H. Jerz and Dr. K. Schwerd, all geologists from Bavaria. Both to all these people, and to the Alexander von Humboldt Foundation, the author wishes to express his sincere thanks.

The purpose of this paper was to compile and describe the Pleistocene formations of the German Alpine foreland glaciers. Glacial geological studies, carried out by the present author, complete the picture of moraines and extent of the Mindel, Riss and Würm Glaciations in the areas of the former Salzach, Inn-Chiemsee, Isar and Iller piedmont glaciers (Glückert 1973 a b, 1974, 1975).

The extent of the oldest Alpine glaciations are not known. The Mindel and Riss Glaciations were the most extensive and covered larger areas of the foreland than the Günz and Würm Glaciations. The Mindel and Riss Galciations often seem to have covered largely the same areas, and the definite mapping of their borders is mainly difficult.

The Mindel Glaciation was the largest glaciation in the areas of the former Salzach, InnChiemsee, Lech and Iller Glaciers, and the Riss in the areas of the Isar and Rhine Glaciers (see e.g. Antevs 1929, Knauer 1938 and Kaiser 1960). According to Graul (1949) and Schaefer (1953 a) the maximum extension of the Donau Glaciation remained not very far behind the Riss in the

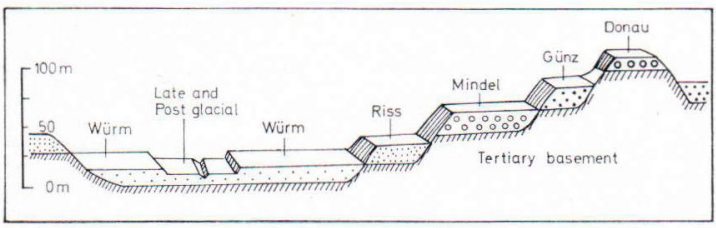

Fig. 3. Schematic profile through a glacial valley with erosion terraces representing the separate Pleistocene glaciations.

Wertach-Lech area, reaching a point between the boundaries of the Riss and Würm Glaciations. A relation with end moraines of the Donau Glaciation, however, has not been found so far. On the Italian side Mindel and Riss deposits have been identified locally outside the Würm moraines (Fig. 1).

Heim (1919 pp. 276-279), Schaefer (1950), Troll (1957) and Fezer (1969), among others, presented values of erosion/accumulation rates in the Alpine Pleistocene formations. During Interglacial periods strong river erosion formed deep valleys through the glacial formations. These terraced valley trains were filled up by glacial accumulation of gravel and till during the following glaciation. Now there exist only remnants of older gravel plains, the greater part of them having been removed by denudation (Fig. 2).

A schematic section across a river valley shows how Pleistocene erosion terraces, sometimes with 4-5 etages, have been formed on both slopes of valley trains (Fig. 3). Young Riss and Würm gravels (High and Low Terrace gravels) occur in the present-day valleys. The remnants of the older covering gravels of the Mindel and Günz Glaciations form high-lying hills on both sides of the terraced valley trains. The higher the gravel deposits lie, the older glaciation they belong to, that is, the oldest Donau and Günz gravels are the highest-lying formations in most of the glacier foreland areas.

The state of hardness and conservation of the gravels varies greatly. The Günz and Mindel 
gravels are hard conglomerates. The younger gravels, especially the Würm gravels, are fresh, unweathered, calcareous, and in loose (not hardened) condition. The Riss gravels are in general covered with loess from the Würmian age. The Riss and Mindel moraines have no dead-ice forms or bogs. The smoothed topography of pre-Würm moraines differs very much from the fresh, sharp shapes of the Würm moraines, with dead-ice formations and bogs.

\section{The Salzach Glacier}

The first noticeable study of the Salzach Foreland Glacier dates back to 1886, when Brückner published his thesis (Brückner 1886). Since the days of Penck and Brückner (1901/09) the foreland of the Salzach Glacier has been the object of several studies on the extent and formations of Pleistocene Glaciations. As a typical foreland glacier, the Salzach Glacier is described in this paper in more detail than the other glaciated areas. This glacier is situated half in West Germany, half in Austria, separated by the River Salzach.

Ebers, Weinberger and Del-Negro's work (1966) includes a marked map of this glacier lobe (Fig. 4). The Salzach Glacier covered ca. 1100 sq. km of the foreland during the Würm Glaciation, and ca. 1700 sq. km during the largest (Mindel) glaciation. The Würm Glacier was ca. $45 \mathrm{~km}$ wide and reached $30 \mathrm{~km} \mathrm{~N}$ from the Alps. The following Pleistocene formations can be distinguished in the area of the former Salzach Glacier (Fig. 4):

- the main terminal basin, with Mindel/Riss, Riss/Würm Interglacial lakes and a Late Glacial lake in the area $\mathrm{N}$ of Salzburg,

- the Würmian ground moraine area, with drumlins and glacial valleys (side terminal basins),

- inner and outer end moraine belts of the Würm Glaciation,

- Würm gravel plains in the front of their end moraines,

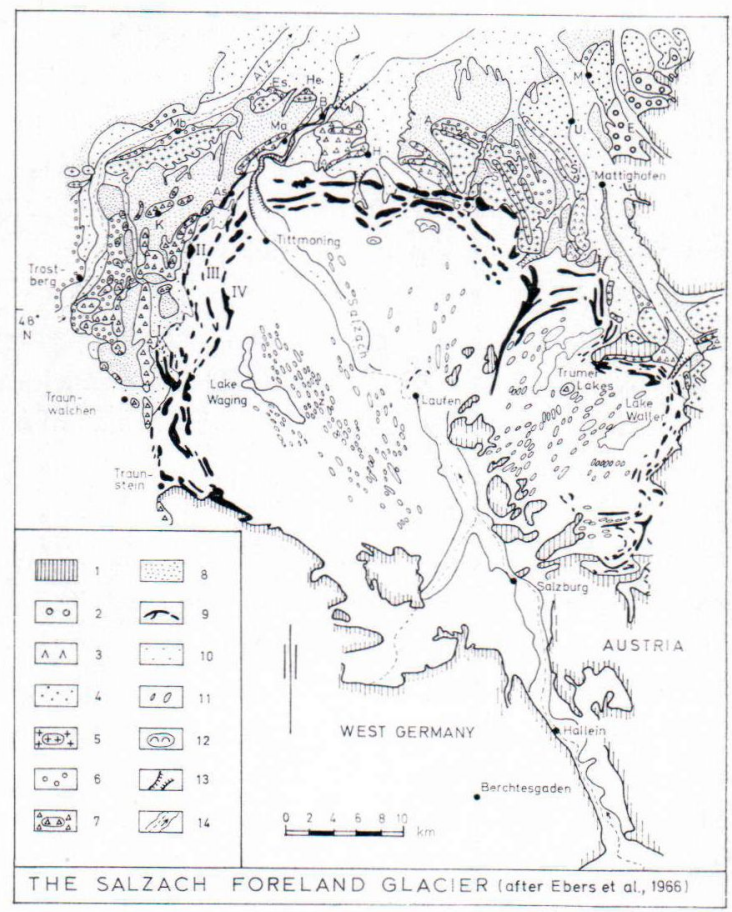

Fig. 4. The Salzach Foreland Glacier (after Ebers et al. 1966). 1. Tertiary and older Alpine rocks, 2. Pre-Günz (Eichwald) gravel, 3. Günz till, 4. Günz gravel, 5. Mindel till, with end moraine ridges, 6. Mindel gravel, 7. Riss till, with end moraine ridges, 8. Riss gravel, 9. Würm till, with end moraine ridges, 10 . Würm gravel, 11. Drumlins, within the ground moraine area, 12. Kames, esker, 13. Meltwater channel, 14. River, with Post-Glacial valley deposits. A Adenberg (Mindel), As Asten (Würm), B Burghausen, E Eichwald (Donau ?), Es Eschlberg (Mindel), G Gundertshausen, H Hochburg (Riss), He Hechenberg (Mindel), K Kirchweidach (Riss), M Mauerkirchen, $\mathrm{Ma}$ Marienberg (Riss), Mb Margarethenberg (Mindel), S Sperledter Rücken (Mindel), Si Siedelberg (Günz ?), Z Zeifen (R/W Interglacial). Main end moraine phases during Würm Glaciation: I the Unterweissenkirchen, II Nunreut, III Radegund and IV Lanzing phases.

- erosion remnants of Riss moraines and gravel plains (as hills and terraces),

- remnants of Mindel moraines and gravels (hills),

- remnants of Günz moraines and gravels (hills), and

- remnants of pre-Günz (Eichwald) gravels (hills).

The outermost wide valleys and low-lying plains (present-day), outside the Mindel and 
Günz formations, are covered with extensive deposits of Würm gravels. The Mindel, Günz and pre-Günz formations are high-lying remnants of former coherent moraine areas and gravel plains, which have been strongly eroded during the younger glacial and Interglacial periods. They are situated on high-lying Tertiary basement, rising now as indefinite hills and ridges from the low-lying Riss and Würm outwash plains (Fig. 4).

The pre-Gïnz-gravels (Eichwald) near Mauerkirchen (Austria) consist of four small remnants. They lie just behind the edge of a large Tertiary massif east of Mattighofen that protected these old Pleistocene formations against denudation (Fig. 4).

Old Pleistocene gravels of the Günz Glaciation, connecting with what are probably Günz moraines at Siedelberg, are known only on both sides of the valley of Utterdorf-Mauerkirchen (Fig. 4).

The Mindel Glaciation had the largest extent among the Pleistocene glaciations in the Salzach area, reaching a point about $5-10 \mathrm{~km}$ outside the border of the Würm Glaciation. The Mindel Glaciation is represented by the marked remnants of end moraine ridges of the Margarethenberg, Eschlberg, Hechenberg, Adenberg and Sperledter Rücken (Fig. 4).

On the northern edge of the Adenberg, the most marked Mindel end moraine in the Salzach area, the Plio/Pleistocene border can be seen in a gravel pit, visited by the author (Fig. 5). Beneath a coarse-grained hardened Mindel till and a blocky layer, the fine-grained Günz sandy gravel, rich in quartz, changes into a loose Tertiary quartz gravel (see also Ebers et al. 1966 pp. $41-42)$.

The end moraines of the Riss Glaciation lie between the Mindel and Würm moraines. The $2-7 \mathrm{~km}$ wide belt of the Riss moraines is distinguished as two parts by Ebers et al. (1966 pp. 58 -61). The outer end moraine between Kirchweidach and Traunwalchen (Riss I) consists of a marked push end moraine complex (see Ebers

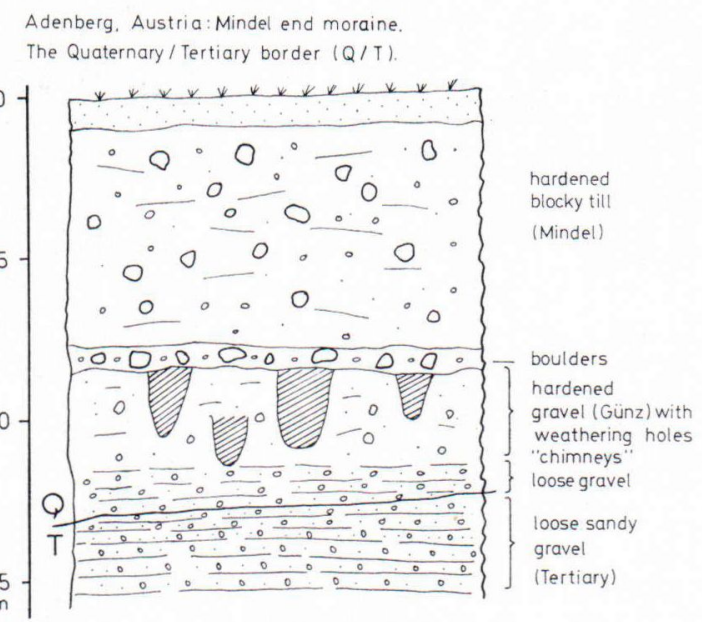

Fig. 5. The Quaternary/Tertiary border in a gravel pit of the Mindel end moraine at Adenberg, the Salzach Glacier (after Glückert).

et al. 1966 pp. 68-72). These push moraines are very rare among the Alpine formations, in contrast to northern Germany (e.g. Gripp 1964, and Glückert $1973 \mathrm{c}$ ). The inner Riss end moraine belt in two parts (R II a and R II b) lies between Traunwalchen, Tyrlaching, Marienberg and SE of Burghausen (Fig. 4).

The most prominent remnants of Riss gravels, covered with loess from the Würmian age, exist between Traunwalchen and Burghausen, around the Mindel moraine isle of Adenberg, and in the valley of Mattighofen (Fig. 4).

The Würm end moraine system consists of four separate broken belts. The outermost end moraine ( $\mathrm{I}$ in Fig. 4) NE of Traunwalchen is short and represents the Unterweissenkirchen phase. The outer (II) of the three main end moraine belts belongs to the Nunreut phase (Würm II), the middle (III) to the Radegund phase and the inner to the Lanzing phase (IV) (Ebers et al. 1966 pp. 150-151) (Fig. 4). During the Early Würm (W I) the glacier did not perhaps extend so far as the Middle Würm (W II) did. According to Ebers et al. (1966) W II thus forms the outermost border during the last glaciation. Between W I and W II there existed 
an Interstadial period, the Laufen Interstadial, ca. 50000 -30000 B.C. (e.g. Ebers et al. 1966 pp. 98-101, and Glückert 1973 b).

The hilly ground moraine area of the Würm Glaciation lies on the inner side of the end moraine belt. There are few drumlin fields, the largest one lying east of Lake Waging (Fig. 4). The ground moraine area seems to be more or less drumlinized, perhaps by an overriding glacier during the Würm maximum (W II), as can be observed in the gravel pit at Schign, S of Lake Waging (Fig. 6) (see also Knauer 1935, and Ebers et al. 1966 pp. 91-95).

East of Lake Waging the famous Interglacial deposit of Zeifen was discovered by Edith Ebers in 1958. In a gravel pit a thick layer of gyttja, rich in fossils, lies beneath Würmian till and gravel (see Ebers et al. 1966 pp. 81-83, and Jung, Beug, and Dehm 1972).

\section{The Inn-Chiemsee Glacier}

The most respected work by Troll (1924) was his study of the large lobe of the former Inn Glacier, connected with the smaller Chiemsee Glacier. He presented the results in »Der diluviale Inn-Chiemsee-Gletscher» and on a detailed map in color. Between these lobes was squeezed the small Prien Glacier (Fig. 7). At the marginal zone of the Alps there were still three small separate valley glacier lobes, the glaciers of Leitzach, Schliersee and Tegernsee (Fig. 2).

The present author has studied two areas within the Inn-Chiemsee Foreland Glacier. Deadice formations, consisting of kame and kettle fields and kame terraces, lie in the lake area of Eggstätt, having been deposited between the Inn and Chiemsee lobes (Glückert 1973 a). In the valley of Törwang, S of Rosenheim, a little Late Würm (?) glacier lobe left a swarm of end moraines with a marked meltwater channel at the front of the glacier tongue (Fig. 7). These terminal moraines have not been mapped before (Glückert 1975).

The Würm moraine area of the Inn-Chiemsee Glacier $(60 \times 65 \mathrm{~km})$ is surrounded on the W and $\mathrm{N}$ by a large Würm outwash and a preWürm moraine belt (chiefly Riss and Mindel), not yet closely studied. The chief terminal basin around Rosenheim during the Late Glacial period formed a big lake. During glaciation the terminal basin branched into several side tongue basins. The Tertiary basement often appears on the slopes of deep valleys. The hilly ground moraine area consists $e . g$. of a couple of drumlin fields (Fig. 7).

The mighty end moraine belt of the InnChiemsee Glacier runs in three parts, as in the area of the Salzach Glacier. The small Würmian Aying phase represents the outermost Unter-

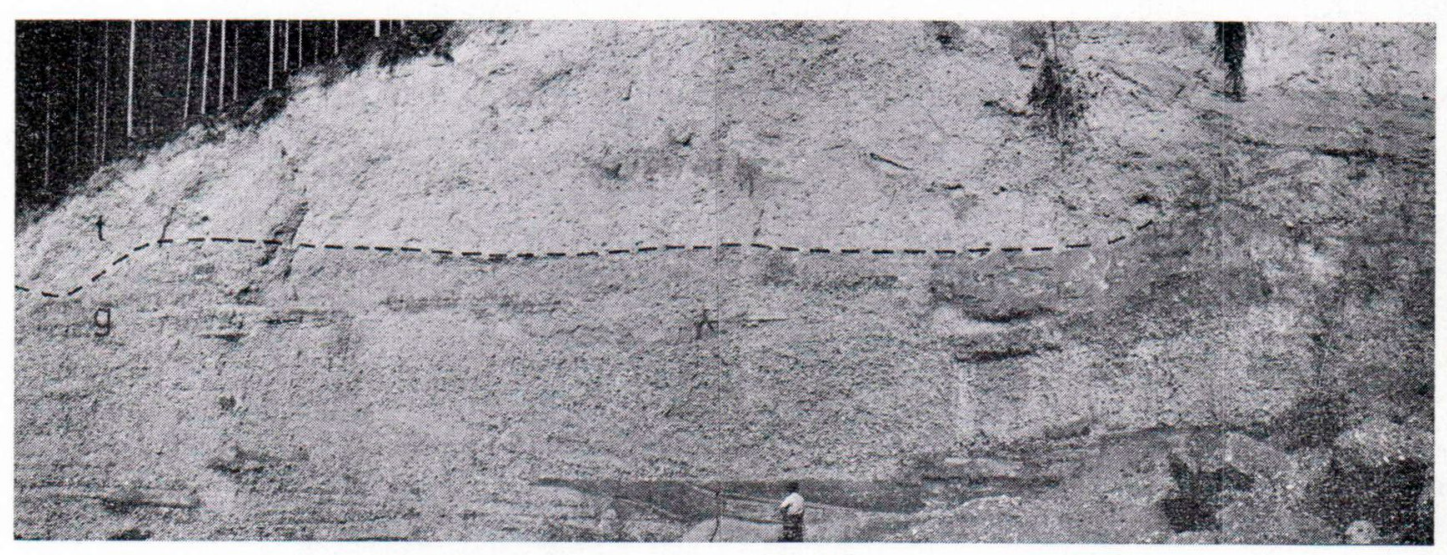

Fig. 6. Till (t) deposited on Würm gravel (g). Schign, S of Lake Waging. Photo Glückert 20. 4. 1972. 


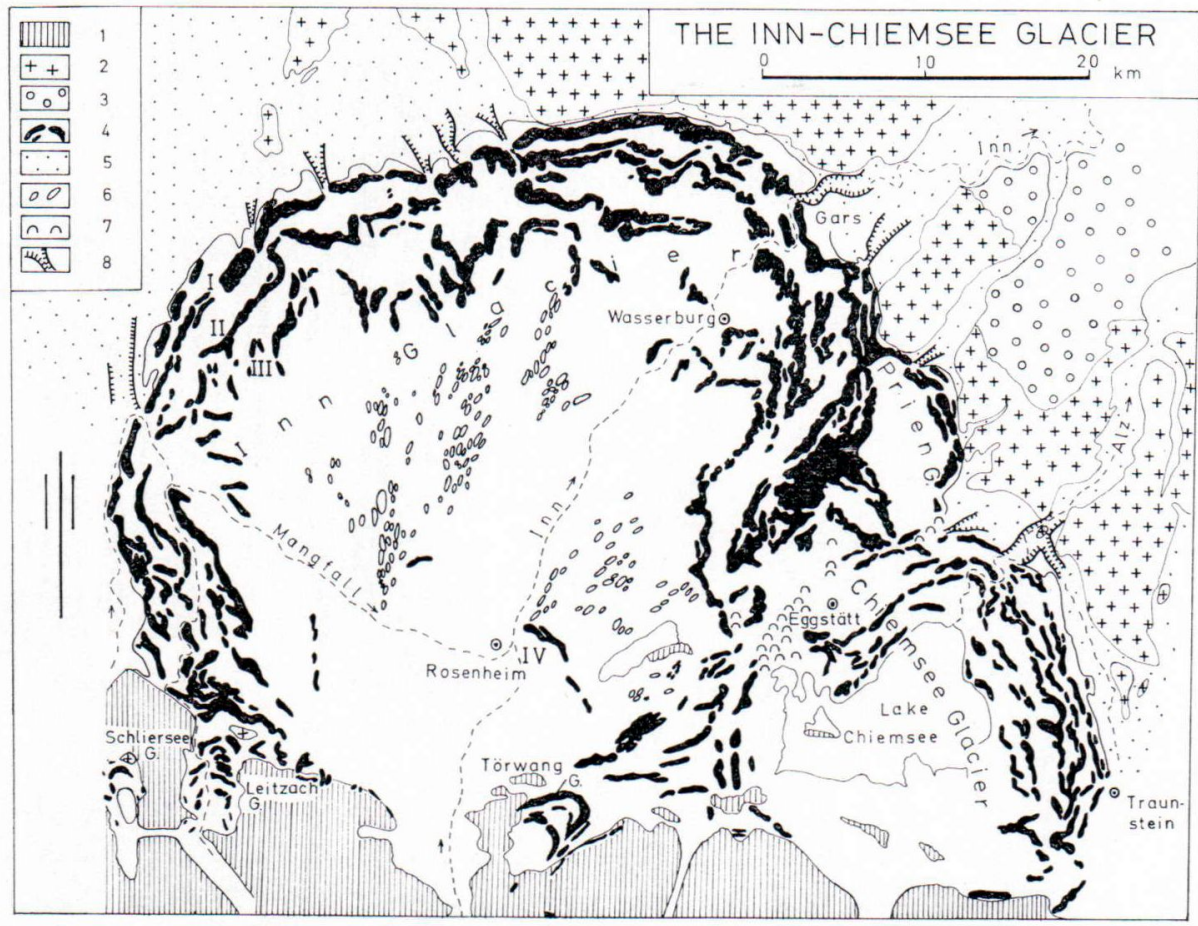

Fig. 7. The Inn-Chiemsee Glacier (mainly by Troll 1924). 1. Tertiary, Alpine rocks, 2. PreWürm moraines, 3. Pre-Würm gravels (mainly Riss), 4. Würm end moraines, 5. Würm gravel, 6. Drumlins, in the Würm moraine area, 7. Kames, 8. Meltwater channel. Würm end moraine phases: I the Kirchseeon, II Ebersberg, III Ölkofen and IV Stephanskirchen phases.

weissenkirchen phase in the Salzach area. The outer main Würmian Kirchseeon phase ( $\mathrm{I}$ in Fig. 7), with several parallel end moraine ridges, belongs to W II. The middle belt of Ebersberg (II in Fig. 7) and the inner belt of Ölkofen (III) consist of several end moraine ridges. In the terminal basin of Rosenheim, the innermost end moraines belong to the Stephanskirchen phase (IV) (Troll 1924, and Kraus and Ebers 1965).

The deep Würm meltwater channel of Gars breaks through the large Würmian end moraine belt at the northern edge of the glacier (the present valley of the River Inn) (Fig. 7). At the bend of the River Mangfall, at the western edge of the glacier, great meltwater masses were driven through a large erosion channel into the western foreland, called the Gravel Field of Munich (Fig. 2 and 7). Between the Inn and Chiemsee lobes there also flowed great melt- water masses along the valley of the river $\mathrm{Alz}$ towards the NE. The famous Würm Interstadial find of Hörmating (peat within Würm gravel) was discovered and described by Ebers (1960 pp. 64 and 75) and dates back to about $45300 \pm$ 1000 B.P.

\section{The Isar Glacier}

The Isar Glacier has been studied e.g. by Aigner (1910, 1913), Rothpletz (1917), Troll (1925), Knauer $(1928,1931)$ and Schmidt-Thomé (1966). The present author has paid particular attention to the little glacier lobe of Tölz, situated between Tölz and Holzkirchen (Fig. 2 and 8).

The $50 \times 50 \mathrm{~km}$ wide Isar Glacier branched into four side terminal basins belonging to the corresponding lobes of Ammersee, Starnberg, 


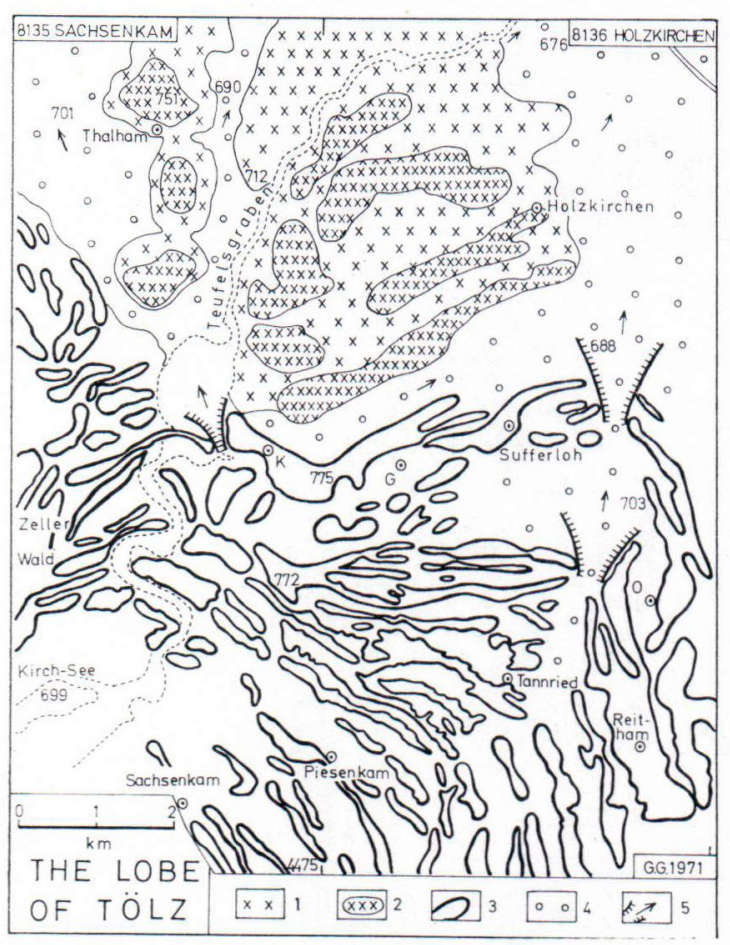

Fig. 8. The lobe of Tölz, the Isar Glacier, near Holzkirchen (mapped by Glückert). 1. Riss moraine, 2. Riss end moraine, 3. Würm end moraine, 4. Würm gravel, 5. Meltwater outflow. G Gross-Hartpenning, K Kleinhartpenning, $\mathrm{O}$ Oberwarngau.

Wolfratshausen and Tölz (Fig. 2). The terminal basin of Ammersee and Starnberg now form long lakes going deep into the Tertiary basement. Also in the basin of the lobe of Wolfratshausen there was a big lake during the Late Glacial period (e.g. Schmidt-Thomé 1966 and Jerz 1969 pp. 60-66).

The moraines and gravels of the Riss Glaciation form the extreme border at the front of the Würmian Isar Glacier (e.g. Penck and Brückner $1901 / 09$ p. 186). The deposits of early Pleistocene Günz and Mindel Glaciations have no distinct forms, but are hidden beneath the Würm and Riss deposits, appearing mostly only as gravel beds in deeply eroded river valleys (e.g. the Isar). Outside Würm moraine area separate Riss moraine isles and remnants of a Riss gravel field rise from even Würm outwash. Along the River Isar, e.g. at Grünwald and Munich, remnants of the Riss gravel field shape terraces rising $10-20 \mathrm{~m}$ above the Würm gravel field, the Gravel Field of Munich, the most extensive coherent gravel accumulation in the foreland of the German Alps (see Penck and Brückner 1901/ 09 pp. 58 - 60, 177, and Schaefer 1968) (Fig. 2).

The well-developed marginal formations of the small Würmian lobe of Tölz, studied by the author in 1971, run into almost twenty separate end moraines (see Aigner 1910, 1913, Rothpletz 1917, Troll 1925, and Schmidt-Thomé 1966). The outermost belt at Gross-Hartpenning and Sufferloh, consisting of ridges $30-40 \mathrm{~m}$ high with sharp crests and steep slopes, runs $S$ of Holzkirchen and is surrounded by a narrow Würm gravel belt. Well-developed end moraine ridges have been formed e.g. in the areas of Oberwarngau, Tannried, Piesenkam and Sachsenkam. The meltwaters of the Würmian lobe break out through two glacier gates lying $\mathrm{S}$ of $\mathrm{Holz}-$ kirchen and in the valley of Teufelsgraben, W of Kleinhartpenning (Fig. 8).

Just $\mathrm{N}$ of the outer Würm end moraines there exist several Riss moraine formations, covered with Würmian loess. A few end moraine ridges can be observed within the Riss moraine area. The deep erosion meltwater valley of Teufelsgraben gives a good cross section of the Pleistocene deposits (Fig. 8).

At Holzkirchen the low Riss moraine hills are covered with loess, more than $1 \mathrm{~m}$ thick. Thin beds of loess were observed by the author also on Würm gravel and in several gravel pits within the Würm gravel field (e.g. SW of Thalham). In a gravel pit in the Zeller Wald, beneath $2 \mathrm{~m}$ till (Würm) a layer of loess $(30 \mathrm{~cm})$ on Würm gravel can be observed. Thin beds of loess within the Würm gravel indicate that there were intervals between the sedimentation of loess and glaciofluvial gravel in the foreland of the Würm glacier.

Swarms of drumlins occur in several areas of the Isar Glacier, e.g. near Königsdorf and west 
of Lake Würm. The well-known drumlin field of Eberfing was studied by Ebers (1926).

A peat layer within the Würm gravel at Höfen $\mathrm{S}$ of Königsdorf gives the ${ }^{14} \mathrm{C}$ age of ca. 35000 B.C. for the Würm Interstadial (Jerz 1969 p. 43 and Stephan 1970 pp. 219, 226-227).

\section{The Lech Glacier}

Just west of the great Ammersee lobe, the Isar Glacier, the small Lech Glacier lies on both

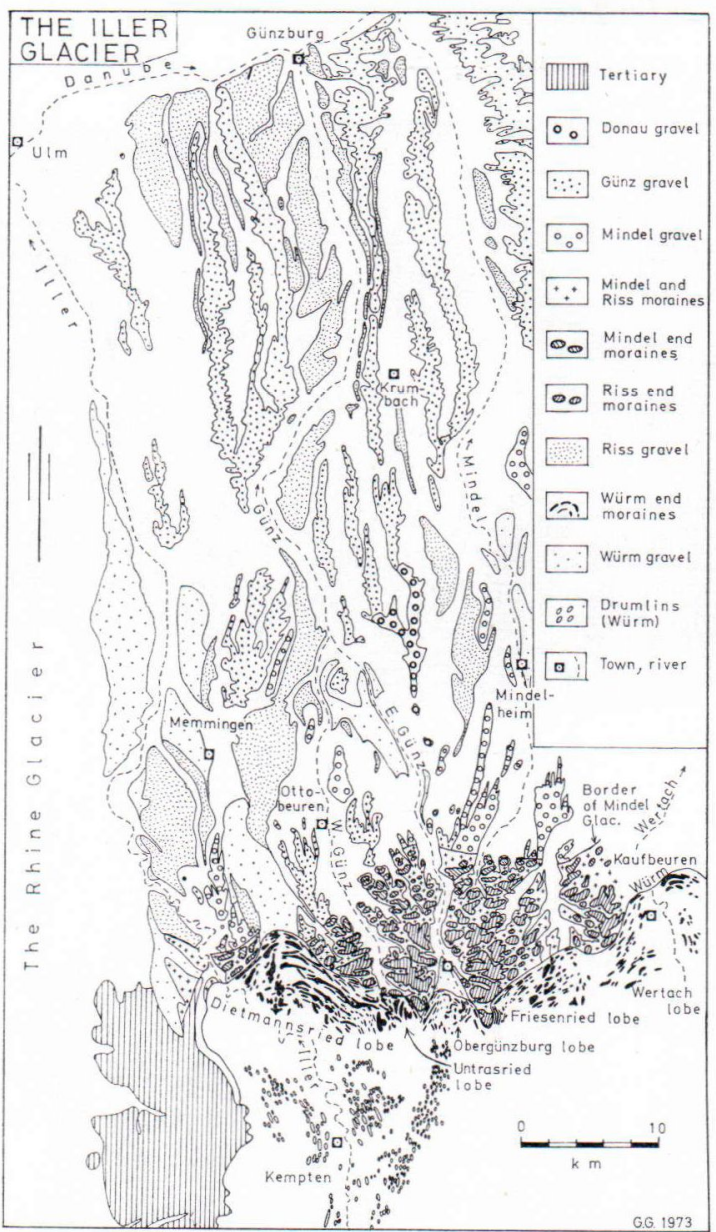

Fig. 9. The Iller Glacier. The moraines after Glückert 1974, the gravels mainly after the Geol. Map of BadenWürttemberg 1:200 000, 1962; and Sinn 1972. White areas in the foreland consist of Tertiary basement and Post-Glacial val'ey sedimer.ts. sides of the River Lech (Fig. 2). The glacier has been studied, e.g. by Penck and Brückner (1901/09), Müller (1918), Eberl (1930) and German (1962). The author has not studied the Lech Glacier personally.

The pre-Würm formations in front of the Würm end moraine belt are remnants, in the main of pre-Riss gravels, Riss moraines and gravel plains, crossing by several marked Würmian centrifugal meltwater channels (Fig. 2).

\section{The Iller Glacier}

Between the Rhine and Lech Foreland Glaciers, the Iller Glacier extended northward during the Würm Glaciation with three large lobes. The western, Kempten lobe and the eastern, Wertach lobe, by the side of the Lech Glacier, are larger than the middle, Günz lobe (Fig. 2 and 9).

Formations of all six known Pleistocene Glaciations were found in the large and manysided foreland of Pleistocene gravel accumulations of the Iller and Lech Glaciers (Eberl 1930 and Schaefer 1956). In the valley of Memmingen, Penck first demonstrated the four major glaciations, i.e. Günz, Mindel, Riss and Würm, by discovering four terraces at different heights belonging to separate glaciations (Penck and Brückner 1901/09 pp. 28-38). Eberl (1930) published his detailed dockument of the LechIller Glacier and also demonstrated the fifth Glaciation (Donau). Later Graul (1949, 1962), Schaefer (1940, 1951, 1953 a, b, 1973), German (1960) and Sinn $(1971,1972)$ have dealt with the formations of the Iller Glacier. Present author has mapped an area with Mindel and Riss end moraines, situating between the rivers of Iller and Wertach, and first distinguished these pre-Würm moraines from each other (Glückert 1974) (Fig. 9).

In the foreland of the Iller moraine area, on both sides of the deeply eroded valley trains, there stretch high-lying long remnants of old gravel fields, belonging to the Donau, Günz, 


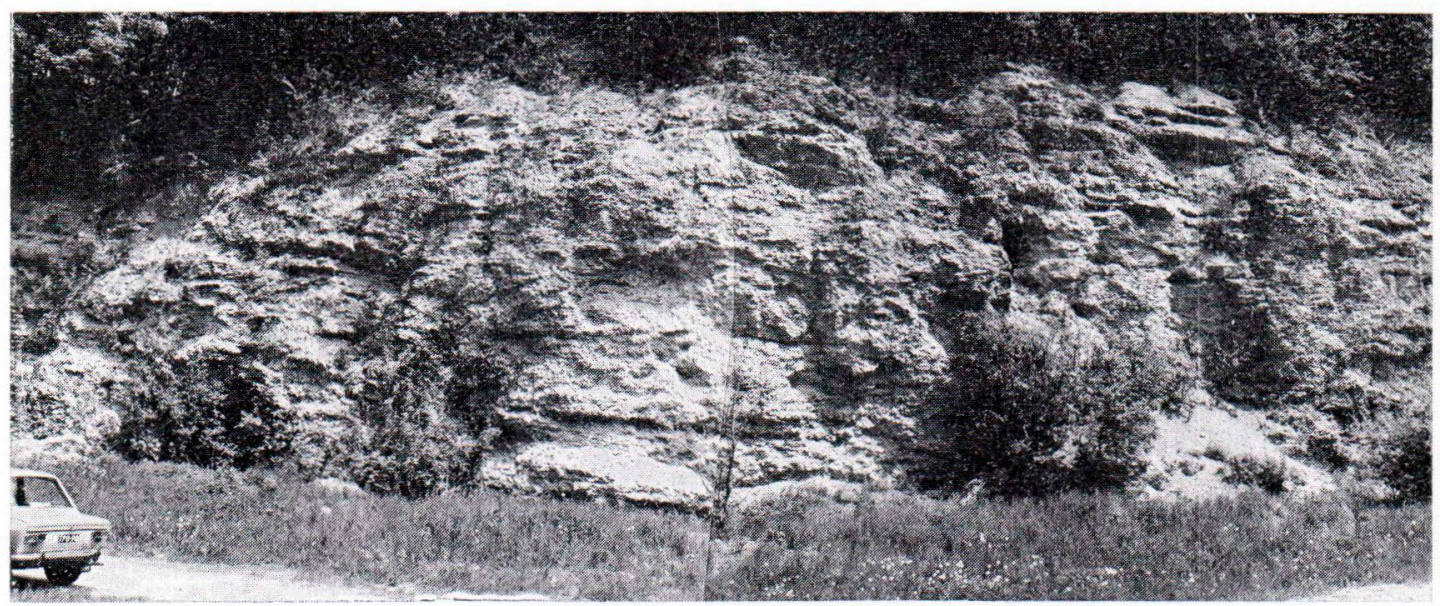

Fig. 10. Hardened Günz gravel of the Iller Glacier. East of Wolfertschwenden. Photo Glückert 4. 6. 1973.

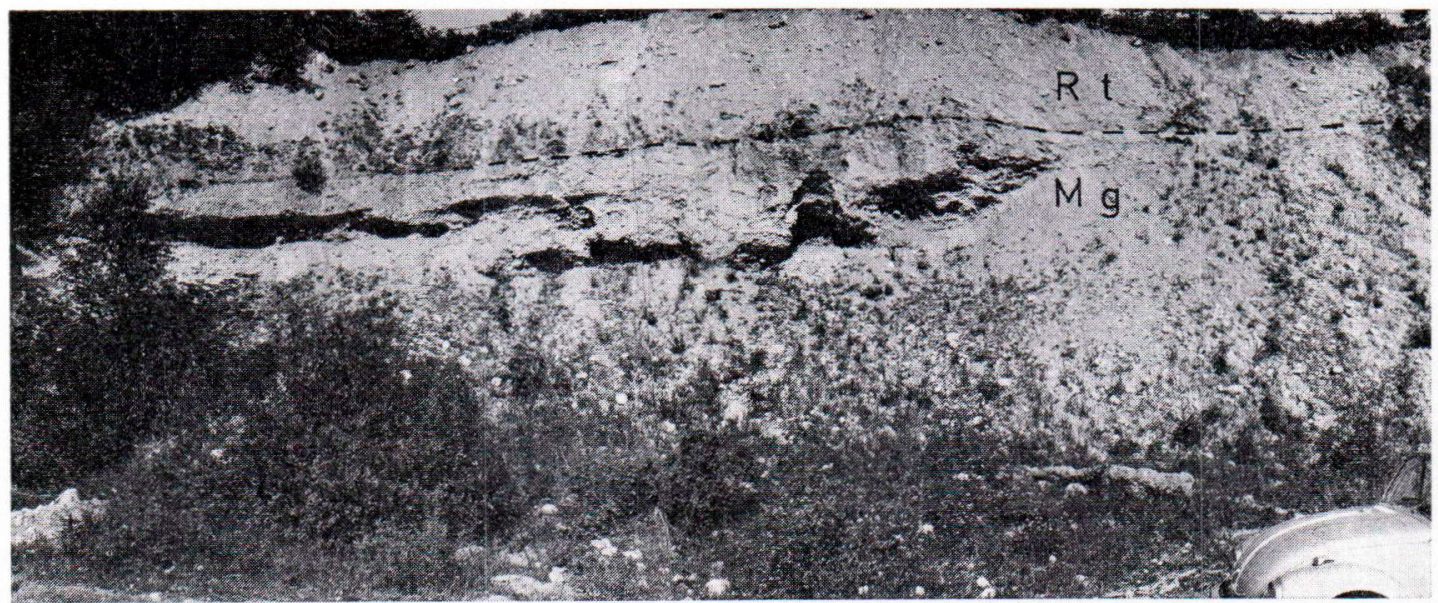

Fig. 11. Riss till ( $\mathrm{R}$ ) above Mindel gravel ( $\mathrm{M}$ ), the Iller Glacier. Hinterschmalholz, SE of Ottobeuren. Photo 4. 6. 1973.

Mindel and Riss Glaciations. At Brüchlins, in the vicinity of Ottobeuren, fine-grained fluvial gravels, called the Ottobeuren gravels, belong to the beginning of the Pleistocene (see Eberl 1930 and Sinn 1972) (Fig. 10).

In the author's opinion, the outer border of the pre-Würm moraines on the even remnants of gravel fields lie further into the foreland than assumed earlier (see the Geol. Map of Baden-Württemberg 1962). The outermost Pleistocene moraines in the area of the former Iller Glacier belong to the Mindel Glaciation.
A lot of the Mindel moraine area, flattened hills rising 5-25 $\mathrm{m}$ above the till-covered gravel fields, has been destroyed by the advance of the younger Riss glacier and by erosion of Riss and Würm meltwater streams (channels). Therefore only the outermost Mindel end moraines exist (Glückert 1974) (Fig. 9).

The $2-10 \mathrm{~km}$ wide zone of the Riss moraines lies .between the borders of the Würm and Mindel Glaciations. The Riss moraine area consists of more than ten belts of broken end moraine ridges, separated by deep Late-Riss 


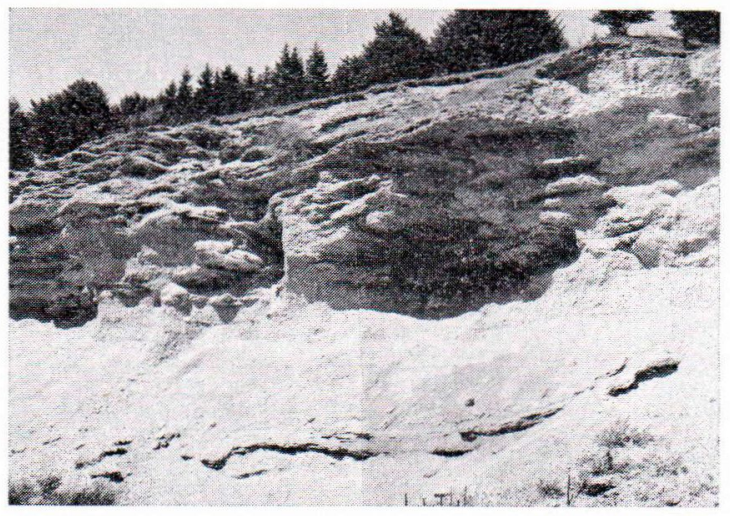

Fig. 12. Riss gravel of the Iller Glacier. Johanniskeller, E of Obergünzburg. Photo Glückert 15. 6. 1973.

and Würm meltwater channels. The most prominent end moraines, e.g. the ridge of the Simmerberg, composed of blocky till lying in layers $10-30 \mathrm{~m}$ thick on gravel and/or Tertiary basement (Fig. 9 and 11). The innermost Riss end moraines have often been destroyed by active tongues of the Würmian Iller Glacier (Glückert 1974) (Fig. 12 and 13).

The Würm gravels fill the bottoms of presentday valleys, e.g. the valleys of Memmingen, western and eastern Günz, Friesenried and
Wertach. During the Würm Glaciation separate small lobes of the Iller Glacier, the lobes of Dietmannsried, Untrasried, Obergünzburg, Friesenried and Kaufbeuren (Wertach), formed several end moraine areas lying in these valleys and closing them as mighty barriers (Glückert 1974) (Fig. 9). The Würm moraines have been studied also by Graul (1953), Schaefer (1953 b) and German (1960).

\section{The Rhine Glacier}

The largest glacier in the foreland of the German Alps is the Rhine Glacier, covering about 6600 sq. $\mathrm{km}(120 \times 60 \mathrm{~km})$ during the Würm and 9700 sq. $\mathrm{km}$ during the largest Pleistocene Glaciation. The large Lake Constance represents the major terminal basin of the glacier. Most of the meltwaters flowed to the both sides of the broad glacier, along the valleys of the Rivers Rhine and Danube, because of a large mountain range, named the Swabian Alp, rising just in the front of the Rhine glacier lobe (Fig. 2 and 14). The Pleistocene formations of the Rhine Glacier have been studied, e.g. by Penck and Brückner (1901/09), Schädel (1953),

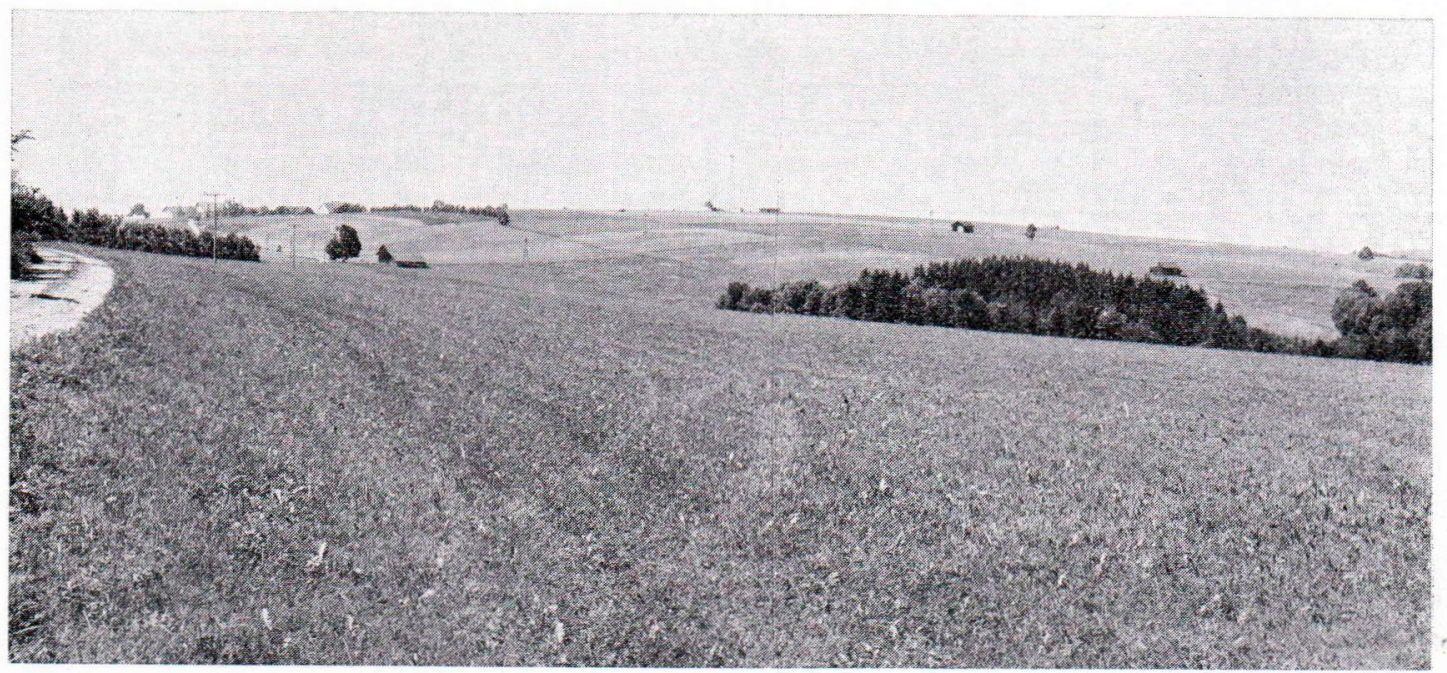

Fig. 13. The highest Riss end moraine ridge of the Iller Glacier: Simmerberg (901 m above sea level), SE of Ottobeuren. Photo Glückert 15. 6. 1973. 


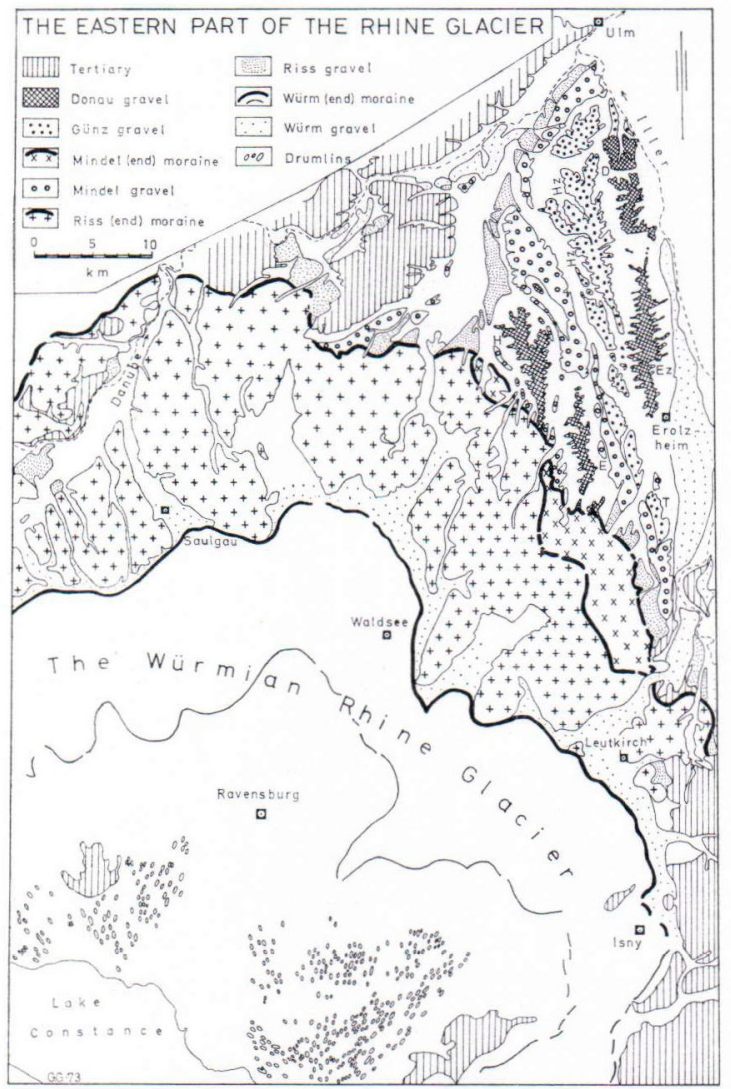

Fig. 14. The eastern part of the Rhine Glacier. Donau and Günz gravel fields: D Dorndorf, E Erlenmoos, Ez Erolzheim, H Heggbach, $\mathrm{Hz}$ Holzstöcke, T Thannheim. White areas within the gravel fields consist of Tertiary basement and Post-Glacial valley deposits. After Penck and Brückner (1901/09), Graul (1962), and the Geol. Maps of Baden-Württemberg (1962), and Iller-Riss (1973).

German (1960), Graul (1962), Eichler (1970) and Mader (1971).

In the western and middle part of the large glacier, the Riss Glaciation reached the largest extent, and in the eastern part the Mindel Glaciation. Both of these glaciations are represented by moraines and gravels. In front of the border of the Riss and Mindel moraines, remnants of Donau and Günz gravel accumulations also occur, e.g. at Erlenmoos, Erolzheim, Heggbach, Dorndorf, Thannheim and Holzstöcke (e.g. Graul 1962, and Schädel and Werner 1963). The gravel accumulations of the Donau, Günz,
Mindel, and Riss Glaciations are deposited between the mountains of the Swabian Alp and the gravels of the Iller Glaciation (Fig. 14).

The Riss moraine area, lying in front of the Würm moraines and gravels, is $10-20 \mathrm{~km}$ wide, consisting of several end moraine belts. The Mindel moraine belt at the eastern edge of the Rhine Glacier lobe is narrow and has not been studied closely yet.

\section{Conclusions}

The study of ancient Pleistocene Glaciations started in the Alps, which still remain one of the principal areas for glacial geological investigations. The famous basic division into the four Alpine Glaciations, the Günz, the Mindel, the Riss and the Würm, was first worked out in detail by Penck and Brückner (1901/09) and completed by Eberl (1930; the Donau Glaciation) and Schaefer (1956; the Biber Glaciation). The formations of the Pleistocene piedmont glaciers consist both of till and end moraines, and of glaciofluvial meltwater gravels, lying in extensive fields in the foreland of the Alpine lobes.

Glacial geological studies were carried out by the author in the areas of several Alpine foreland glaciers, the former Salzach, Inn-Chiemsee, Isar and Iller Glaciers. These results complete the picture of the Pleistocene formations of the Günz, Mindel, Riss and Würm Glaciations. Large areas covered by the former Alpine glaciations, however, have not yet been studied closely.

In the foreland of the Salzach, Inn-Chiemsee, Iller and the eastern part of the Rhine Glaciers Mindel moraines have been identified outside the Riss and Würm moraines. The Riss Glaciation was the most extensive in the areas of the former Isar and western part of the Rhine Glaciers. The considerable erosion of ancient glacial deposits has formed deep valley trains, with terraced slopes belonging to particular glaciations. 
The Salzach Glacier is a typical area with deposits of five glaciations. This foreland glacier has been studied by Brückner, Penck and Ebers et al. The Plio/Pleistocene border can be observed, e.g. in a gravel pit situated on the ridge of Adenberg, the outermost Pleistocene and most marked Mindel end moraine in the area. The Mindel, Riss and Würm end moraine belts indicate the borders of the former glacier lobes. The Würm moraines are partly drumlinized, forming several drumlin fields.

The large lobes of the Inn-Chiemsee Glacier have been mapped in detail by Troll. Outside the mighty Würm end moraine belt, which is in three parts, the Kirchseeon, Ebersberg and Ölkofen phases, a large pre-Würm moraine area is situated, which has not yet been closely studied. Both the dead-ice formations between the Inn and Chiemsee lobes, and the Late Würmian end moraines in the closed valley of Törwang, were studied more closely by the present author.

During the Würm Glaciation the Isar Foreland Glacier formed four separate lobes, the Ammersee, Starnberg, Wolfratshausen and Tölz. Outside their mighty end moraine ridges, separate remnants of Riss moraines and gravels rise as isolated hills above one of the largest gravel accumulations in the northern Alpine foreland, the Gravel Field of Munich. A well-developed swarm of more than 20 Würmian end moraine ridges represent the small Tölz lobe, which was studied by the author.
The small Lech Glacier lies between the Isar and Iller Glaciers. Outside the Würm moraines Riss moraines and pre-Würm gravels have been observed.

Finally, the Iller Foreland Glacier was studied by the author in 1973, to distinguish the Mindel and Riss moraines from each other. The remnants of the narrow Mindel end moraine belt lie outside the wide Riss end moraines, cut into separate ridges by strong glacial meltwater and interglacial fluvial erosion. These pre-Würm moraines lie on high remnants of the Günz and Mindel gravel plains on both sides of the deep eroded valley trains. The Würmian end moraines were deposited by small tongues of the Iller Glacier, moving along the bottoms of pre-Würm valleys, thrusting in some areas over part of the Riss moraine area. In the Iller-Lech Foreland the oldest Pleistocene and largest pre-Würm gravel deposits have been found, belonging chiefly to the Biber, Donau and Günz Glaciations.

The Rbine Glacier, the westernmost and largest former glacier lobe in the northern Alpine foreland, was squeezed against the mountain range of the Swabian Alp. The pre-Würm formations, belonging to the Donau, Günz, Mindel and Riss Glaciations, therefore lie outside the borders of the Würmian lobe, mainly NE of the former glacier. The broad Riss moraine area in front of the Würm formations is especially prominent. A narrow Mindel moraine zone has been identified outside the Riss area in the eastern part of the glacier.

\section{REFERENCE}

Argner, Damasus (1910) Das Tölzer Diluvium. Geographisch-geologische Untersuchungen auf dem Gebiete der oberbayersichen Glazialablagerungen zwischen Loisach und Schlierach. Mitt. Geogr. Ges. in München 5. 159 p.

- (1913) „Das Tölzer Diluvium» und »Die Glazialbildungen zwischen Tölz und Holzkirchen». Mitt. Geogr. Ges. in München, 8 (4): 491-511.
Antevs, Ernst (1929) Maps of the Pleistocene Glaciations. Bull. Geol. Soc. Am. 40: 631-720.

BRÜCKNER, EDUARD (1886) Die Verletscherung des Salzach-Gebietes. Geogr. Abh. I, Wien. 183 p.

Eberl, Barthel (1930) Die Eiszeitfolge im nördlichen Alpenvorlande. Ihr Ablauf, ihre Chronologie auf Grund der Aufnahmen im Bereich des Lech- und Illergletschers. Augsburg. 427 p. 
Ebers, Edith (1926) Das Eberfinger Drumlinfeld. Geognostische Jahresh. 39: 47-86.

- (1960) Drumlinkerne, ältere Würmschotter und das Würm-Interstadial-Profil von Hörmating/Obb. Eiszeitalter und Ggw. 11: 64-76, Öhringen/Württ.

Ebers, Edith; Weinberger, Ludwig and Del-Negro, WALTER (1966) Der Pleistozäne Salzachvorlandgletscher (with a map, 1: 100000 ). Veröffentlichungen der Ges. für Bayerische Landeskunde e.V., München. $216 \mathrm{p}$.

Eichler, Horst (1970) Das präwürmzeitliche Pleistozän zwischen Riss und oberer Rottum. Ein Beitrag zur Stratigraphie des nordöstlichen Rheingletschergebietes. Heidelberger Geogr. Arb. 30. 128 p.

FEZER, Fritz (1969) Tiefenverwitterung circumalpiner Pleistozänschotter. Heidelberger Geogr. Arb. 24. 144 p.

Geologische Karte von Bayern, 1: 500 000. Bayerisches Geologische Landesamt, München, 1964 (Geological map of Bavaria).

Geologische Übersichtskarte von Baden-Württemberg, 1 : 200 000. Geologisches Landesamt Baden-Württemberg, 1962 (Geological map of Baden-Württemberg).

German, Rüdrger (1960) Die Würmvereisung im Rheinund Illergletscher zwischen Federseebecken und Günztal. Geol. Bavarica 43: 3-73.

- (1962) Zur Geologie des Lechvorlandgletschers. Jber. u. Mitt. Oberrh. Geol. Ver. N.F. 44: 61-83.

Glückert, Gunnar (1973 a) Toteisgebict zwischen Rimsting und Eggstätt an der Naht des Inn- und Chiemsee-Vorlandgletschers (Oberbayern). Summiry. Mitt. Geogr. Ges. in München 58: 45-51.

- (1973 b) ${ }^{14} \mathrm{C}$-Alter eines interstadialen Torfes in der postglazialen Hammerau-Terrasse und eines Moores unter Kalktuff bei Tittmoning an der Salzach (Oberbayern). Eiszeitalter und Ggw. 23/24: 371-376.

- (1973 c) Glazialmorphogenese der weichseleiszeitlichen Moränen des Eckernförder Zungenbeckens (Schleswig-Holstein). Meyniana 23: 19-48.

- (1974) Mindel- und risseiszeitliche Endmoränen des Illervorlandgletschers. Eiszeitalter und Ggw. 25: 96-106.

- (1975) Eisrandlagen im Törwanger Becken bei Nussdorf am Inn (Oberbayern). Geol. Bavarica (in print).

Graul, Hans (1949) Zur Gliederung des Altdiluviums zwischen Wertach-Lech und Flossach-Mindel. 2. Ber. Naturf. Ges. Augsburg.

- (1953) Zur Gliederung der Würmeiszeit im Illergebiet. Geol. Bavarica 18: 13-48.

- (1962) Eine Revision der pleistozänen Stratigraphie des schwäbischen Alpenvorlandes. Petermanns Geogr. Mitt. 106: 253-271.

- (1968) The Present State of Quaternary Stratigraphy in the Western Foreland of the German Alps. Uni- versity of Colorado Studies, Series in Earth Sciences, No. 7, Glaciation of the Alps. Proceedings of the VII Congress - Vol. 14. International Union for Quaternary Research 1965: 3-7. Boulder, Colorado.

Gripp, KARL (1964) Erdgeschichte von SchleswigHolstein. Neumünster. 411 p.

Heim, Albert (1919) Geologie der Schweiz Band I. Molasseland und Juragebirge. Leipzig. 704 p.

Jerz, Hermann (1969) Erläuterungen zur Geologischen Karte von Bayern 1 : 25 000, Blatt Nr. 8134 Königsdorf. Bayerisches Geol. Landesamt. München. 173 p. Jung Walter, Hans-Jürgen Beug and Richard Dehm (1972) Das Riss/Würm Interglazial von Zeifen, Landkreis Laufen a.d. Salzach. Bayerische Akademie der Wissenschaften. Mathematisch-Naturwissenschaftliche Klasse, Neue Folge, Heft 151. 131 p. München.

KaISER, Karlhernz (1960) Klimazeugen des periglazialen Dauerfrostbodens in Mittel- und Westeuropa. Eiszeitalter und Ggw. 11: 121-140.

KnaUer, J. (1928) Glazialgeologische Ergebnisse aus dem Isargletscher Gebiet. Z. der deutsch. Geol. Ges. 80.

- (1931) Erläuterungen zur geognostischen Karte von Bayern 1:100 000, Teitblatt München-Starnberg. Geol. Landesuntersuchg. am Bayer. Oberbergamt. 48 p.

- (1935) Die Ablagerungen der älteren Würmeiszeit (Vorrückungsphase) im süddeutschen und norddeutschen Vereisungsgebiet. Abh. Geol. Landesuntersuchg. am Bayer. Obergamt 21. 65 p.

- (1938) Die Mindel-Eiszeit, die Zeit grösster diluvialer Vergletscherung in Süddeutschland. Abh. Geol. Landesuntersuchg. am Bayer. Oberbergamt 29.

Kraus, E. and Edith Ebers (1965) Die Landschaft um Rosenheim. Quellen und Darstellungen zur Geschichte der Stadt und des Landkreises Rosenheim, Band IV. $244 \mathrm{p}$.

Kraus, Ernst C. (1968) The Glaciogenetic Sequence of the Four Classical Glaciations of Albrecht Penck Exposed in Full Continuity in Southern Germany. Proceedings of the VII Congress - Vol. 14. International Union for Quaternary Research. University of Colorado Studies, Ser. in Earth Sciences 7, Glaciation of the Alps, pp. 15-25, Boulder, Colorado.

Mader, Matriras (1971) Das Quartär zwischen Adelegg und Hochgelände (Bildungsweise und Stratigraphie). Jh. Ges. Naturkunde Württemberg 126: 178-205.

Müller, J. (1918) Die diluviale Vergletscherung und Übertiefung im Lech- und Illergebiet. Ein Beitrag zur Frage der Übertiefung. Jahrbuch preuss. geol. Landesamt. 38, Tl. 1., Berlin.

Penck, Albrecht and Eduard Brückner (1901/1909) Die Alpen im Eiszeitalter I-III, Leipzig. 
Rothpletz, A. (1917) Die Osterseen und der Isar-Vorlandgletscher. Eine geologische Schilderung der Umgebung der Osterseen und ihrer Beziehungen zur Vorlandvergletscherung. Mitt. Geogr. Ges. in München 12 (2): $99-314$.

Schaefer, Ingo (1940) Die Würmeiszeit im Alpenvorland zwischen Riss und Günz. Abh. Naturkunde- u. Tiergartenverein f. Schwaben e.V. Augsburg H. 11. $148 \mathrm{p}$.

-(1950) Die diluviale Erosion und Akkumulation. Über die Talbildung im Alpenvorland. Forschungen zur. deutsch. Landes- und Volkskunde 49. 154 p.

- (1951) Quartärgeologische Exkursion durch die RissLech-platte. Geol. Bavarica 6: 98-114.

- (1953 a) Die donaueiszeitlichen Ablagerungen an der Lech und Wertach. Geol. Bavarica 19: 13-64.

- (1953 b) Zur Gliederung der Würmeiszeit im Illergebiet. Stellungnahme zu den Ausführungen. $\mathrm{H}$. GRAUL'S. Geol. Bavarica 18: 49-112.

- (1956) Sur la division du Quaternaire dans l'avant-pays des Alpes en Allmagne. Actes IV Congr. Inqua II, Rom 1: $910-914$.

- (1968) Münchner Ebene und Isartal. Ein Beitrag zur Frage ihrer Entstehung. Mitt. Geogr. Ges. in München 53: 175-203.

- (1973) Das Grönenbacher Feld. Ein Beispiel für Wandel und Fortschritt der Eiszeitforschung seit Albrecht Penck. Eiszeitalter und Ggw. 23/24; $168-200$.

Schmidt-Thomé, Paul (1966) Geologische Skizze des Isartal-Gebietes zwischen Bad Tölz u. München; Karte 1:100 000, 1966 (Geological Map of the Isar Glacier $1: 100$ 000).

SchäDel, K. (1953) Die Stratigraphie des Altdiluviums im Rheingletschergebiet. Jber. u. Mitt. Oberrh. Geol. Ver. 34. 20 p.

Schädel, K. and J. Werner (1963) Neue Geschichtspunkte zur Stratigraphie des mittleren und älteren Pleistozäns im Rheingletschergebiet. Eiszeitalter und Ggw. 14: 5-26.

SinN, Peter (1971) Zur Ausdehnung der Donau-Vergletscherung im schwäb:schen Alpenvorland. Eiszeitalter und Ggw. B. Mitteilungen 22: 188-191.

- (1972) Zur Stratigraphie und Paläogeographie des Präwürm im mittleren und südlichen IllergletscherVorland. Heidelberger Geogr. Arb. 37. 153 p.

Stephan, Walter (1970) Frühwürmzeitliche Schieferkohlevorkommen im Bereich des östlichen Isar-Vorlandgletschers. Geol. Bavarica 63: 217-230.

Troll, Karl (1924) Der diluviale Inn-Chiemsee-Gletscher. Das geographische Bild eines typischen Alpenvorlandgletschers. (with a geol. map, 1:100 000). Forschungen zur deutsch. Landes- und Volkskunde 23 (1). $121 \mathrm{p}$.

- (1925) Die Rückzugsstadien der Würmeiszeit im nördlichen Vorland der Alpen. Mitt. Geogr. Ges. in München 18 (1/2): 282-292.

- (1957) Tiefenerosion, Seitenerosion und Akkumulation der Flüsse im fluvioglazialem und periglazialem Bereich. Machatschek-Festschrift, Gotha.

Woldstedt, Paul (1967) The Quaternary, Vol. 2, edited by Kalervo Rankama. New York. 477 p.

- (1969) Quartär. Handbuch der stratigraphischen Geologie II, Stuttgart. 256 p.

Übersichtskarte des Iller-Riss-Gebiets $1: 100$ 000. Geol. Landesamt Baden-Württemberg 1973 (Geological Map of the Iller-Riss area $1: 100000$ ).

Manuscript received, February 6, 1974. 